\title{
Anionic Ring-Opening Polymerization of Phenylsilacyclobutanes
}

\author{
Kozo Matsumoto, ${ }^{\dagger}$ Masaaki SHInohata, and Hitoshi YamaOKA \\ Department of Polymer Chemistry, Kyoto University, \\ Kyoto 606-8501, Japan \\ (Received October 23, 1999)
}

\begin{abstract}
Butyllithium-induced anionic ring-opening polymerization of phenyl-substituted silacyclobutanes was investigated. Polymerization of 1,1-dimethyl-3-phenylsilacyclobutane in tetrahydrofuran (THF) at $-78^{\circ} \mathrm{C}$ proceeded in a living fashion. A linear relationship between $\ln [\mathrm{M}]_{0} /[\mathrm{M}]$ and time $\left([\mathrm{M}]_{0}\right.$ is the initial concentration of the monomer and $[M]$ is the concentration of monomer) and a linear relationship between number-average molecular weight $\left(M_{n}\right)$ and monomer conversion were observed. The molecular weight of the obtained polymer was very narrow $\left(M_{w} / M_{n}=1.09, M_{w}\right.$ is weight-average molecular weight). In contrast, neither 1,1-dimethyl-2-phenylsilacyclobutane nor 1-methyl-1phenylsilacyclobutane showed a living nature under the same polymerization conditions, which were confirmed by twostep monomer addition experiments. ${ }^{13} \mathrm{C}$ NMR and ${ }^{29} \mathrm{Si}$ NMR spectrum of the poly(1,1-dimethyl-2-phenylsilacyclobutane) indicated that polymerization of 1,1-dimethyl-2-phenylsilacyclobutane proceeded without regioselectivity. By differential scanning calorimetry (DSC) measurements, glass transition temperatures $\left(T_{\mathrm{g}}\right)$ s were determined at $-5^{\circ} \mathrm{C}$ for poly(1,1-dimethyl-3-phenylsilacyclobutane), $27^{\circ} \mathrm{C}$ for poly(1,1-dimethyl-2-phenylsilacyclobutane), and $-29^{\circ} \mathrm{C}$ for poly $(1-$ methyl-1-phenylsilacyclobutane).

KEY WORDS Silacyclobutane / Phenylsilacyclobutane / Living Anionic Polymerization / RingOpening Polymerization / Polysilacyclobutane /
\end{abstract}

Silacyclobutane is an important monomer to synthesize polycarbosilanes and many researchers have studied the polymerization of silacyclobutanes in detail during the last half century. ${ }^{1,2}$ Recently, we reported the living anionic polymerization of 1,1-dimethyl and 1,1diethyl-substituted silacyclobutanes. ${ }^{3}$ Knischka and coworkers reported the living anionic polymerization of 1,1-dipropylsilacyclobutane. ${ }^{4}$ However, the living polymerization of silacyclobutane derivatives other than 1,1dialkylsilacyclobutanes remains unknown.

Phenyl group substituted monomers are quite attractive because the physical and mechanical properties of polymeric materials are strongly affected by aromatic substituents. Therefore, we studied the anionic ringopening polymerization of 1-phenyl, 2-phenyl, and 3phenyl substituted silacyclobutanes in detail. The polymerization of 1,1-dimethyl-3-phenylsilacyclobutane gave a living polysilacyclobutane, while those of the other two monomers did.

\section{EXPERIMENTAL}

\section{Materials}

1,1-Dimethyl-3-phenylsilacyclobutane (1) was synthesized in four steps from $\alpha$-methylstyrene (Scheme 1). 2Phenyl-2-propen-1-ol was prepared as reported. ${ }^{5} 2$ Phenyl-3-chloro-1-propene was prepared by treatment of 2-phenyl-2-propene-1-ol with triphenylphosphine in tetrachloromethane. ${ }^{6}$ Platinum-catalyzed hydrosilation of the olefin with chlorodimethylsilane and successive exposure of the product to magnesium provided the desired monomer 1 in good yield.

1,1-Dimethyl-2-phenylsilacyclobutane (2) was prepared as reported. ${ }^{7}$ 1-Methyl-1-phenylsilacyclobutane (3) was prepared by treatment of 1-chloro-1-methyl-

\footnotetext{
${ }^{\dagger}$ To whom correspondence should be addressed
}

silacyclobutane with phenylmagnesium bromide. Triphenylphosphine, tetrachloromethane, magnesium, hexachloroplatinic acid, lithium, and butyllithium hexane solution were purchased from Wako Pure Chemical Industry, chlorodimethylsilane and 3-chloropropylmethyldichlorosilane from Shin-Etsu Chemical, and used as delivered. Tetrahydrofuran (THF) was freshly distilled over sodium benzophenone ketyl under argon atmosphere before use. Phenylmagnesium bromide was prepared by treatment of phenyl bromide with magnesium in THF. Lithium naphthalene was prepared by treatment of naphthalene with lithium metal in THF.

\section{Measurements}

Gel-permeation chromatography was carried out in chloroform on a JASCO 880-PU chromatograph equipped with four polystyrene gel columns (Shodex K$802, \mathrm{~K}-803, \mathrm{~K}-804$, and $\mathrm{K}-805$; exclusion limit $=5 \times$ $10^{3}, 7 \times 10^{4}, 4 \times 10^{5}$, and $4 \times 10^{6}$, respectively) and JASCO 830-RI refractive index detector. Molecular weights of the polymers were calibrated with polystyrene standards. ${ }^{1} \mathrm{H}$ and ${ }^{13} \mathrm{C}$ NMR spectra were recorded on a JEOL GSX 270 spectrometer in $\mathrm{CDCl}_{3} \cdot{ }^{29} \mathrm{Si} \mathrm{NMR}$

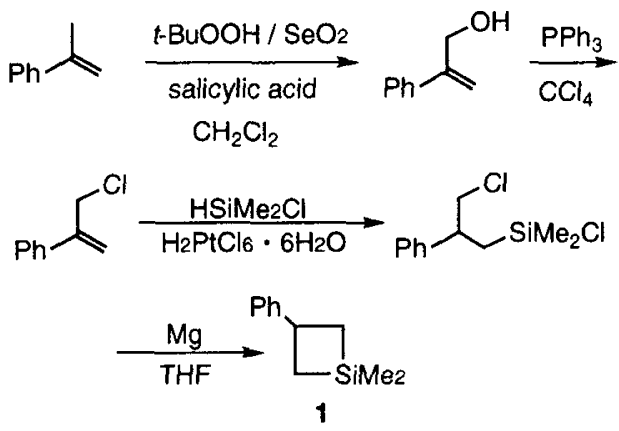

Scheme 1. 
spectra were recorded on a JEOL GSX 500 spectrometer in $\mathrm{CDCl}_{3}$. Tetramethylsilane was used as the internal standard for NMR measurement. IR spectra were measured on a JASCO IR-810 spectrometer. Differential scanning calorimetry (DSC) measurements were performed on a MAC Science DSC 3100 at -100 to $+150^{\circ} \mathrm{C}$ and found to be reproducible with no apparent hysteresis over three heating and two cooling scans. Glass transition temperature $\left(T_{\mathrm{g}}\right)$ was determined from the inflection point on the DSC curve easily observed in the differential calculus of DSC curves (DDSC).

\section{Preparation of Chloro(3-chloro-2-phenylpropyl)dimethyl- silane}

A magnetic stirring bar and catalytic amount of hexachloroplatinic acid (10 $\mathrm{mg})$ were charged in a two-necked $100 \mathrm{~mL}$ round bottomed flask equipped with a reflux condenser, dropping funnel, and rubber balloon. The flask was filled with argon. 3-Chloro-2-phenyl-1-propene $(13.0 \mathrm{~g}, 85 \mathrm{mmol}$ ) was added and the mixture was heated to $50^{\circ} \mathrm{C}$. Chlorodimethylsilane $(11.0 \mathrm{~mL}, 99 \mathrm{mmol})$ was slowly added to the mixture which was then stirred for 3 $\mathrm{h}$ at $50^{\circ} \mathrm{C}$. Excess chlorodimethylsilane was removed with a rotary evaporator under reduced pressure. Direct distillation of the resulting residue under reduced pressure gave the title compound $(15.0 \mathrm{~g}, 61 \mathrm{mmol})$ in $72 \%$ yield : bp $80^{\circ} \mathrm{C}$ (0.3 Torr); IR (neat) $3026,2952,1495$, $1256,831,808,699 \mathrm{~cm}^{-1} ;{ }^{1} \mathrm{H} \mathrm{NMR}\left(\mathrm{CDCl}_{3}\right) \delta 0.11(\mathrm{~s}, 3$ $\mathrm{H}), 0.19(\mathrm{~s}, 3 \mathrm{H}), 1.28(\mathrm{dd}, J=11.0,14.7 \mathrm{~Hz}, 1 \mathrm{H}), 1.57$ (dd, $J=4.4,14.7 \mathrm{~Hz}, 1 \mathrm{H}$ ), 3.19 (dddd, $J=4.4,7.3,7.3$, $11.0 \mathrm{~Hz}, 1 \mathrm{H}), 3.67$ (dd, $J=7.3 .13 .2 \mathrm{~Hz}, 1 \mathrm{H}$ ), 3.69 (dd, $J$ $=7.3,13.2 \mathrm{~Hz}, 1 \mathrm{H}), 7.20-7.41(\mathrm{~m}, 5 \mathrm{H}) ;{ }^{13} \mathrm{C} \mathrm{NMR}$ $\left(\mathrm{CDCl}_{3}\right) \delta$ 1.65, 2.50, 23.69, 43.80, 51.78, 127.40, 127.70, 128.64, 141.98. Anal. Calcd. for $\mathrm{C}_{11} \mathrm{H}_{16} \mathrm{Cl}_{2} \mathrm{Si}$ : C, $53.44 \% ; \mathrm{H}, 6.52 \%$. Found : C, 53.54\% ; H, 6.71\%.

\section{Synthesis of 1,1-Dimethyl-3-phenylsilacyclobutane (1)}

A magnetic stirring bar and magnesium $(3.0 \mathrm{~g}, 123$ mmol) were charged into a three-necked $300 \mathrm{~mL}$ round bottomed flask equipped with a reflux condenser, dropping funnel, and rubber balloon. The flask was filled with argon. First, THF (10 mL) and 1,2-dibromoethane $(0.6 \mathrm{~mL})$ were added and the mixture was heated by a heat gun to activate the magnesium. After an exothermic reaction, a solution of chloro(3-chloro-2phenylpropyl)dimethylsilane $(15.0 \mathrm{~g}, 61 \mathrm{mmol})$ in $\mathrm{THF}$ $(90 \mathrm{~mL})$ was slowly added over a period of $10 \mathrm{~min}$. The mixture was then heated to reflux and stirred for $1 \mathrm{~h}$. The mixture was poured into ice-cooled $1 \mathrm{M} \mathrm{HCl}(200$ $\mathrm{mL})$ and the products were extracted with hexane (300 $\mathrm{mL}$ ). The organic layer was washed four times with water $(200 \mathrm{~mL})$ and dried over anhydrous $\mathrm{Na}_{2} \mathrm{SO}_{4}$ and concentrated. The residue was distilled over $\mathrm{CaH}_{2}$ to give the title compound $(8.2 \mathrm{~g}, 47 \mathrm{mmol})$ in $77 \%$ yield : bp $37^{\circ} \mathrm{C}$ (0.3 Torr) ; IR (neat) 2956, 2904, 1602, 1491, $1248,1108,866,848,807,749,712,695 \mathrm{~cm}^{-1} ;{ }^{1} \mathrm{H}$ NMR $\left(\mathrm{CDCl}_{3}\right) \delta 0.27(\mathrm{~s}, 3 \mathrm{H}), 0.35(\mathrm{~s}, 3 \mathrm{H}), 1.07-1.22(\mathrm{~m}, 2 \mathrm{H})$, $1.41-1.57(\mathrm{~m}, 2 \mathrm{H}), 3.41$ (tt, $J=8.8,11.7 \mathrm{~Hz}, 1 \mathrm{H}), 7.07-$ $7.16(\mathrm{~m}, 1 \mathrm{H}), 7.18-28(\mathrm{~m}, 4 \mathrm{H}) ;{ }^{13} \mathrm{C} \mathrm{NMR}\left(\mathrm{CDCl}_{3}\right) \delta-$ 2.24, 1.26, 22.89, 36.62, 125.21, 125.87, 128.01, 149.83. Anal. Calcd. for $\mathrm{C}_{11} \mathrm{H}_{16} \mathrm{Si}$ : C, 74.93\%; H, $9.15 \%$. Found : C, $74.78 \% ; \mathrm{H}, 9.34 \%$. The monomer was redistilled over $\mathrm{LiAlH}_{4}$ (bp $37^{\circ} \mathrm{C} / 0.3$ Torr) just before a poly- merization.

\section{Synthesis of 1,1-Dimethyl-2-phenylsilacyclobutane (2)}

The title compound was prepared as reported, ${ }^{7}$ and distilled twice over calcium hydride under reduced pressure before use. Spectral data were in accordance with those reported previously.

\section{Synthesis of 1-Methyl-1-phenylsilacyclobutane (3)}

In a $500 \mathrm{~mL}$ round-bottomed flask equipped with a magnetic stirring bar, reflux condenser, dropping funnel, rubber septum, and rubber balloon, were placed magnesium $(2.91 \mathrm{~g}, 120 \mathrm{mmol})$ and THF $(20 \mathrm{~mL})$ under argon atmosphere. $0.8 \mathrm{~mL}$ of 1,2-dibromoethane was added, and the mixture was heated by a heat gun to activate the magnesium. A solution of 3-chloropropylmethyldichlorosilane $(19.2 \mathrm{~g}, 100 \mathrm{mmol})$ in THF $(80 \mathrm{~mL})$ was slowly added to the magnesium over a period of $1 \mathrm{~h}$. After stirring the mixture for $2 \mathrm{~h}$ at room temperature, a solution of phenylmagnesium bromide (1.76 $\mathrm{M}$ in THF, $65 \mathrm{~mL}, 114 \mathrm{mmol}$ ) was added at $0^{\circ} \mathrm{C}$ and the mixture was stirred for $2 \mathrm{~h}$ at room temperature. The solution was poured into $1 \mathrm{M}$ aqueous $\mathrm{HCl}$ and the products were extracted with hexane $(200 \mathrm{~mL} \times 2)$. The organic layer was washed with water, dried over anhydrous $\mathrm{Na}_{2} \mathrm{SO}_{4}$, and concentrated. The residual oil was distilled over $\mathrm{CaH}_{2}$ under reduced pressure to give the title compound $(13.3 \mathrm{~g}, 82.2 \mathrm{mmol})$ in $82 \%$ yield : bp 33 ${ }^{\circ} \mathrm{C}$ (0.3 Torr) ; IR (neat) 2960, 2924, 1429, 1250, 1113, $866,771,731,696 \mathrm{~cm}^{-1} ;{ }^{1} \mathrm{H}$ NMR $\left(\mathrm{CDCl}_{3}\right) \delta 0.55(\mathrm{~s}, 3$ $\mathrm{H}), 1.10-1.40(\mathrm{~m}, 4 \mathrm{H}), 2.19(\mathrm{tt}, J=8.8,8.8 \mathrm{~Hz}, 2 \mathrm{H})$, $7.30-7.43(\mathrm{~m}, \quad 3 \mathrm{H}), \quad 7.58-7.70(\mathrm{~m}, 2 \mathrm{H}) ;{ }^{13} \mathrm{C} \mathrm{NMR}$ $\left(\mathrm{CDCl}_{3}\right) \delta-1.87,14.27,18.19,127.86,129.36,133.42$, 138.57. Anal. Calcd. for $\mathrm{C}_{10} \mathrm{H}_{14} \mathrm{Si}: \mathrm{C}, 74.00 \% ; \mathrm{H}, 8.69 \%$. Found : $\mathrm{C}, 73.84 \%$; $\mathrm{H}, 8.83 \%$. The monomer was redistilled over $\mathrm{CaH}_{2}$ just before a polymerization.

\section{Polymerizations of Phenylsilacyclobutanes}

In a $50-\mathrm{mL}$ round-bottomed flask equipped with a magnetic stirring bar, rubber septum, and rubber balloon, was placed THF (6 mL) under argon atmosphere. The solvent was titrated with a THF solution of lithium naphthalene to eliminate all reactive impurities. The mixture was cooled to $-78^{\circ} \mathrm{C}$, butyllithium $(1.00 \mathrm{M}$ hexane solution, $0.15 \mathrm{mmol}$ ) was added, and then phenylsilacyclobutane $(3.0 \mathrm{mmol})$. The reaction mixture was stirred for the designated period. Water $(0.5 \mathrm{~mL})$ was added to terminate the polymerization. The resulting mixture was poured into water $(50 \mathrm{~mL})$ and extracted with ether $(50 \mathrm{~mL})$. The organic layer was washed with water $(50 \mathrm{~mL})$ and dried over anhydrous $\mathrm{Na}_{2} \mathrm{SO}_{4}$. The volatile fractions were removed by evaporation. Monomer conversion was determined by ${ }^{1} \mathrm{H}$ NMR measurement of the crude products. The products were dissolved in a small amount of toluene and precipitated into excess methanol. The precipitate was dried in vacuo to give a poly(phenylsilacyclobutane).

\section{Poly(1,1-dimethyl-3-phenylsilacyclobutane)}

IR (neat) 3022, 2948, 2896, 1602, 1493, 1454, 1412, 1247, 1175, 870, 761, $700 \mathrm{~cm}^{-1} ;{ }^{1} \mathrm{H} \mathrm{NMR}\left(\mathrm{CDCl}_{3}\right) \delta$ $(-0.61(\mathrm{~s}),-0.50(\mathrm{~s}),-0.41(\mathrm{~s})$, total $108 \mathrm{H}),(-0.31(\mathrm{~s})$, $-0.22(\mathrm{~s})$, total $6 \mathrm{H}), 0.18-0.31(\mathrm{~m}, 2 \mathrm{H}), 0.45-1.01(\mathrm{~m}$, 
$77 \mathrm{H}), 1.05-1.30(\mathrm{~m}, 7 \mathrm{H}), 2.44-2.78(\mathrm{~m}, 19 \mathrm{H}), 6.92-$ $7.28(\mathrm{~m}, 95 \mathrm{H}) ;{ }^{13} \mathrm{C} \mathrm{NMR}\left(\mathrm{CDCl}_{3}\right) \quad \delta \quad-2.48,-2.39$, $29.10,29.23,29.30,37.97,125.70,127.17,128.07$, 128.18, 149.16. Anal. Calcd. for $\mathrm{C}_{11} \mathrm{H}_{16} \mathrm{Si}$ : C, 74.93\%; $\mathrm{H}, 9.15 \%$. Found : C, $74.74 \% ; \mathrm{H}, 9.19 \%$.

\section{Poly(1,1-dimethyl-2-phenylsilacyclobutane)}

IR (neat) 3056, 3023, 2886, 1602, 1495, 1448, 1415, $1244,1037 \mathrm{~cm}^{-1} ;{ }^{1} \mathrm{H}$ NMR $\left(\mathrm{CDCl}_{3}\right) \delta-0.27(\mathrm{~s}, 3 \mathrm{H})$, $-0.18--0.08(\mathrm{~m}, 3 \mathrm{H}), 0.06-0.22(\mathrm{~m}, 1 \mathrm{H}), 0.35-0.55$ $(\mathrm{m}, 1 \mathrm{H}), 1.34-1.68(\mathrm{~m}, 2 \mathrm{H}), 1.72-1.84(\mathrm{~m}, 1 \mathrm{H}), 6.71-$ $6.90(\mathrm{~m}, 2 \mathrm{H}), 6.92-7.27(\mathrm{~m}, 3 \mathrm{H}) ;{ }^{13} \mathrm{C} \mathrm{NMR}\left(\mathrm{CDCl}_{3}\right) \delta$ $-4.79,-4.54,-4.50,-4.45,-4.41,13.99,23.48$, $39.66,39.75,124.16,127.83,127.93,143.41,143.44$; ${ }^{29} \mathrm{Si} \mathrm{NMR}\left(\mathrm{CDCl}_{3}\right) \delta 3.12,3.11,3.06,3.04$. Anal. Calcd. for $\mathrm{C}_{11} \mathrm{H}_{16} \mathrm{Si}: \mathrm{C}, 74.93 \%$; H, 9.15\%. Found : C, $74.65 \%$; $\mathrm{H}$, $9.19 \%$.

\section{Poly(1-methyl-1-phenylsilacyclobutane)}

Spectral data of the title compound were reported previously. ${ }^{3 \mathrm{~b}}$

\section{Two-Step Monomer Addition Experiment}

One hour after the addition of phenylsilacyclobutane $(3.0 \mathrm{mmol})$ to a solution of butyllithium $(0.15 \mathrm{mmol})$ in THF $(6 \mathrm{~mL})$, the same monomer $(3.0 \mathrm{mmol})$ was added without quenching polymerization, and the solution was stirred for another hour or a specified period. The workup procedures were the same as described above.

\section{RESULTS AND DISCUSSION}

\section{Polymerization of 1,1-Dimethyl-3-phenylsilacyclobutane}

Since 1,1-dimethyl-3-phenylsilacyclobutane (1) has a phenyl group situated far from the silicon atom, the polymerization was expected to proceed in the same way as that of simple 1,1-dialkylsilacyclobutane. ${ }^{3 \mathrm{~b}}$

Polymerization of 1 was carried out in THF at $-78^{\circ} \mathrm{C}$ using butyllithium as initiator (Scheme 2). Polymerization of twenty-fold mole of monomer 1 by butyllithium was almost complete within $1 \mathrm{~h}$. The number-average molecular weight $\left(M_{n}\right)$ of the obtained polymer was 4100 (estimated by GPC relative to polystyrene standards), which was almost equal to that calculated from the initial ratio of the monomer to initiator $\left([\mathrm{M}]_{0} /[\mathrm{I}]_{0}\right.$, calculated $M_{n}=3600$ ). Figure 1 shows the ${ }^{1} \mathrm{H}$ NMR spectrum of the obtained polymer, which confirmed the clean formation of atactic poly(1,1-dimethyl-3-phenylsilacyclobutane). Assignments of the signals are given in the figure. Signals due to the termination end methyl group $\mathbf{l}$ and two methylene groups $\mathbf{b}$ and $\mathbf{c}$ in the initiation end butyl group were observed at $1.05-1.30 \mathrm{ppm}$. The timeconversion curve of the polymerization is shown in Figure 2. Polymerization started readily without induction period, and was almost complete in $60 \mathrm{~min}$. The polymerization restarted smoothly by the second supply of monomer at $60 \mathrm{~min}$ (two-step monomer addition) and proceeded at the same rate as in the first step. A linear relationship between $\ln \left([\mathrm{M}]_{0} /[\mathrm{M}]\right)$ and time seen in Figure 3 indicated no termination in the polymerization. The relationship between $M_{n}$ and monomer conversion is shown in Figure 4. The linear relationship between $M_{n}$ and monomer conversion suggested that no chain

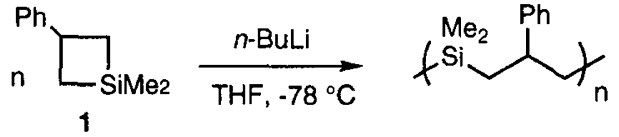

Scheme 2.

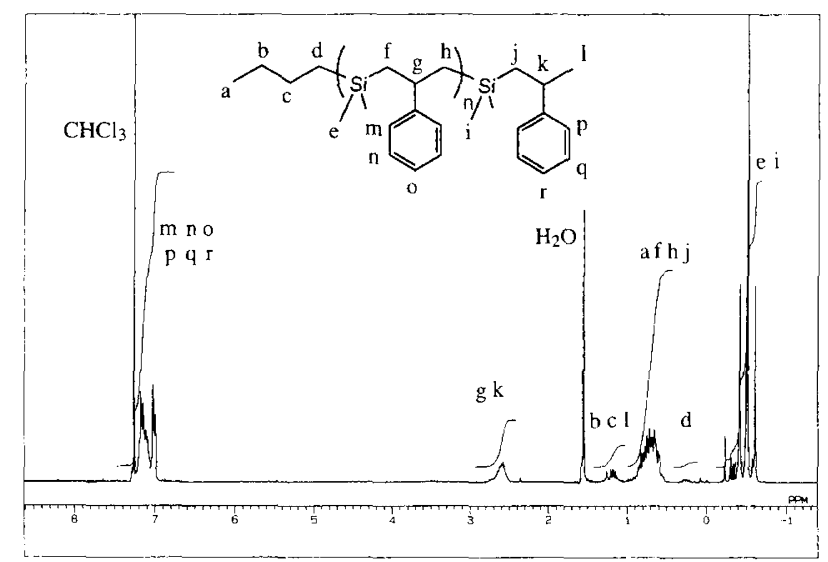

Figure 1. ${ }^{1} \mathrm{H}$ NMR spectrum of poly(1,1-dimethyl-3-phenylsilacyclobutane).

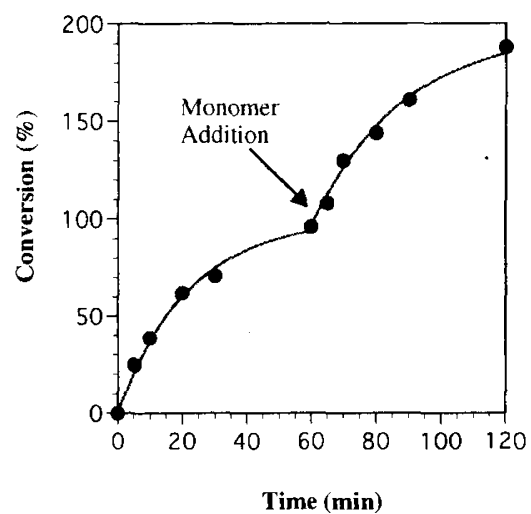

Figure 2. Time-conversion curve for the polymerization of monomer 1 . The second fresh supply of monomer was added at $60 \mathrm{~min}$. The conversion is based on the amount of first-step monomer addition.

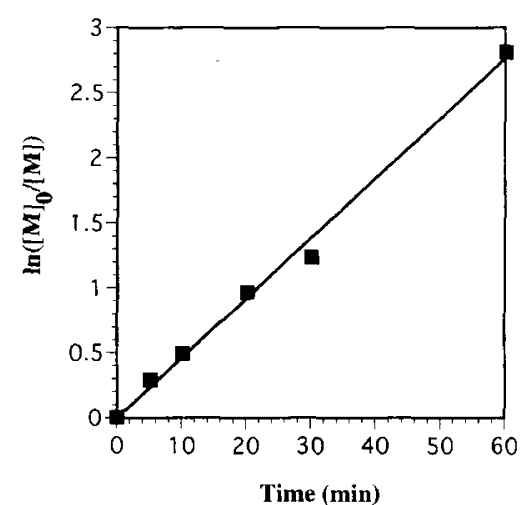

Figure 3. Time $-\ln \left([\mathrm{M}]_{0} /[\mathrm{M}]\right)$ relationship of the polymerization of monomer $\mathbf{1}$. 


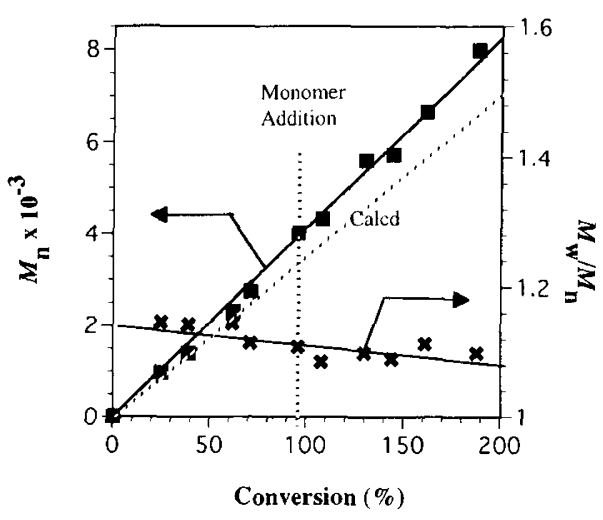

Figure 4. $M_{n}$-conversion relationship and $M_{w} / M_{n}$-conversion relationship of the polymerization of monomer 1 . The second fresh supply of monomer was added at $60 \mathrm{~min}$. The conversion is based on the amount of first-step monomer addition.

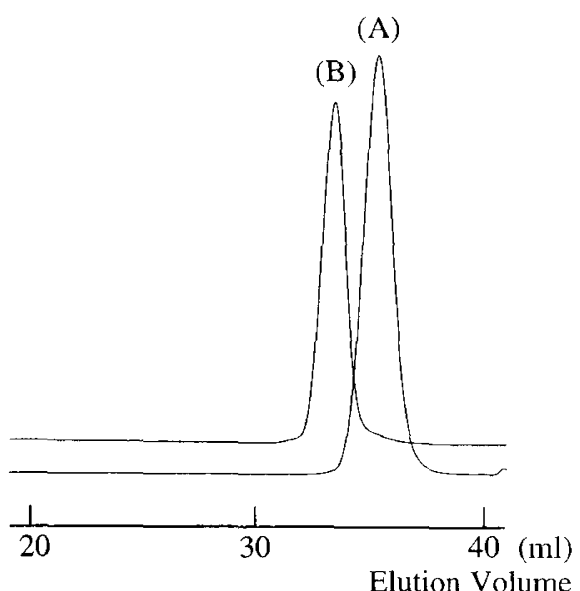

Figure 5. GPC charts: (A) poly(1,1-dimethyl-3-phenylsilacyclobutane) obtained after completion of the first polymerization step ; (B) poly(1,1-dimethyl-3-phenylsilacyclobutane) obtained after completion of the second polymerization step.

transfer during the polymerization, although $M_{n}$ was estimated relative to polystyrene standards. Even after the second addition of monomer to the polymerization mixture, $M_{n}$ continued to increase linearly with monomer conversion. The relation of molecular weight distribution $\left(M_{w} / M_{n}\right.$, where $M_{w}$ is weight average-molecular weight) to monomer conversion is given in Figure 4. $M_{w} J$ $M_{n}$ remained narrow $(<1.15)$ even after the second addition of monomer. Gel permeation chromatogram (GPC) of the obtained polymers before and after the addition of the second supply of the monomer shifted to a higher molecular weight region, keeping monomodal distribution (Figure 5). The polymerization of monomer 1 was thus concluded to proceed in a living fashion.

\section{Polymerization of 1,1-Dimethyl-2-phenylsilacyclobutane}

1,1-Dimethyl-2-phenylsilacyclobutane (2) is interesting because the four-membered ring has $\mathrm{Si}-\mathrm{C}$ bonds, a benzylic $\mathrm{Si}-\mathrm{C}$ bond $\mathbf{a}$ and normal alkyl $\mathrm{Si}-\mathrm{C}$ bond $\mathbf{b}$, as shown in Figure 6. Since Gilman and Atwell reported that the addition of 1,1,2-triphenylsilacyclobutane to excess phenyllithium in diethyl ether afforded triphenyl(3lithio-3-phenylpropyl)silane as well as polymeric materi-

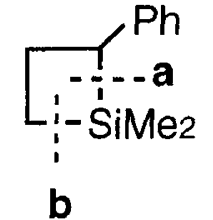

Figure 6. Chemical structure of 1,1-dimethyl-2-phenylsilacyclobutane (2).

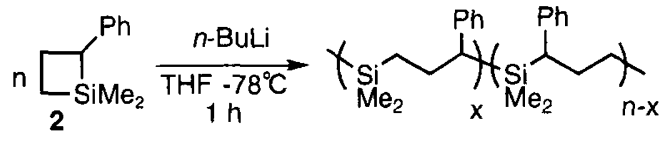

Scheme 3.

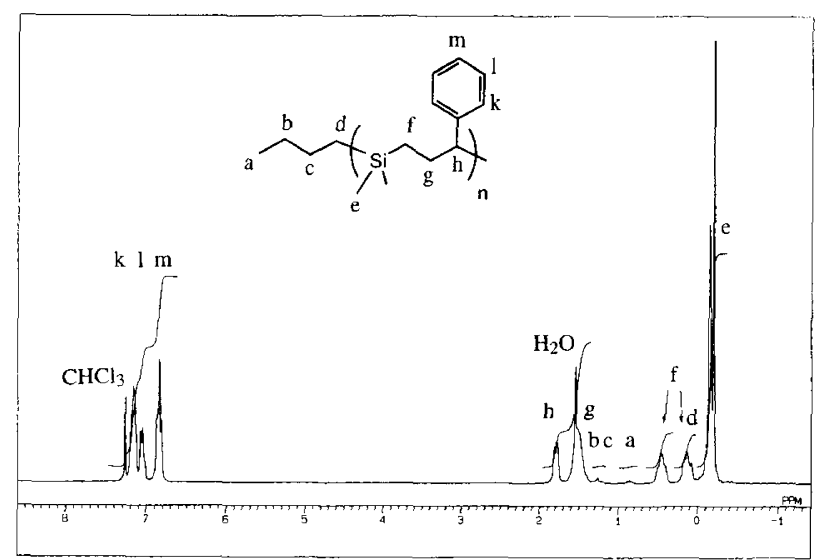

Figure 7. ${ }^{1} \mathrm{H}$ NMR spectrum of poly(1,1-dimethyl-2-phenylsilacyclobutane).

als, ${ }^{8}$ we expected that a regioselective ring-opening polymerization with cleavage of bond a might occur to provide a regular polymer with narrow molecular weight distributions in the anionic polymerization.

The polymerization proceeded much faster than that of monomer 1 under the same polymerization conditions. Polymerization of twenty-fold mole of monomer 2 to the initiator was complete almost instantly after the addition of the monomer. $M_{n}$ of the obtained polymer was 75000 (estimated by GPC relative to standard polystyrenes), which was much higher than that calculated from $[\mathrm{M}]_{0} /[\mathrm{I}]_{0}$ (the calculated $M_{n}=3600$ ). $M_{w} / M_{n}$ of the polymer was quite broad (2.39).

The ${ }^{1} \mathrm{H}$ NMR spectrum of the obtained polymer is shown in Figure 7. Assignments are given in the figure. The signal at $0.78-0.92 \mathrm{ppm}$ may be due to the methyl protons in the initiation end butyl groups and protons of unidentified impurities. The signal at $1.20-1.30 \mathrm{ppm}$ may be due to the methylene protons in the initiation end butyl groups. The termination end benzylic methylene group was not observed. To examine in more detail, we took ${ }^{29} \mathrm{Si}$ NMR of the polymer. The ${ }^{29} \mathrm{Si}$ NMR spectrum is shown in Figure 8. Four signals were observed at $3.04,3.06,3.11$, and $3.12 \mathrm{ppm}$. Figure 9 depicts all possible chemical structures for the connection between the two monomer units. ${ }^{29} \mathrm{Si}$ chemical shifts of aa-cis and aa-trans would appear at the same position as in the case of ba-cis and ba-trans did. There is little elec- 


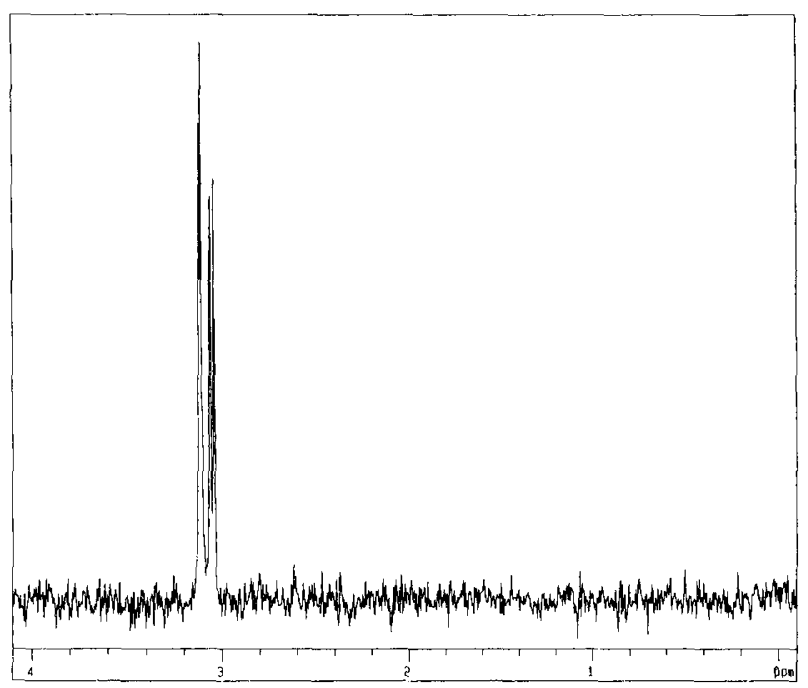

Figure 8. ${ }^{29} \mathrm{Si}$ NMR spectrum of poly(1,1-dimethyl-2-phenylsilacyclobutane)
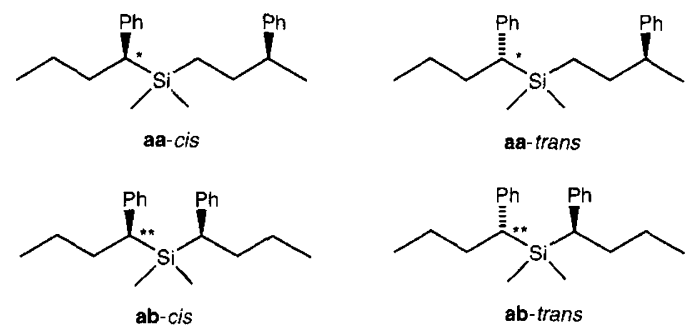

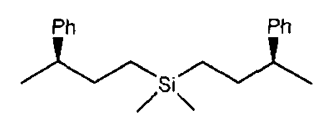

ba-cis

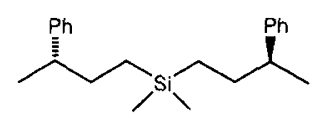

ba-trans
Figure 9. Six possible microstructures of poly(1,1-dimethyl-2phenylsilacyclobutane).

tromagnetic difference between these stereoisomeric silicon atoms presumably because the stereogenic centers are located far from the silicon atoms. Four signals were thus seen separately. ${ }^{13} \mathrm{C}$ NMR signals of benzylic carbons were observed at 39.66 and $39.75 \mathrm{ppm}$ (Figure 10), due to benzylic carbons of aa-cis and -trans $\left({ }^{*}\right)$, and those of ab-cis and -trans $\left({ }^{* *}\right)$. The ring-opening polymerization of monomer 2 may thus possibly proceed without regioselectivity to give a polymer through cleavage at $\mathbf{a}$ and $\mathbf{b}$ (Scheme 3 ).

The benzylic $\mathrm{Si}-\mathrm{C}$ bond seems more susceptible to cleavage than the alkyl $\mathrm{Si}-\mathrm{C}$ bond but the benzylic anion seems less reactive than the alkyl anion. This may explain why the polymerization did not show any regioselectivity.

To examine the living nature of the polymer prepared above, a two-step monomer addition experiment was attempted. The second fresh supply of monomer 2 was added to the polymerization mixture, 60 min after the first step. Although all added monomer was converted to poly(1,1-dimethyl-2-phenylsilacylobutane), no increase in molecular weight was observed as shown in Figure 11. Most of the polymer chain ends appeared to have

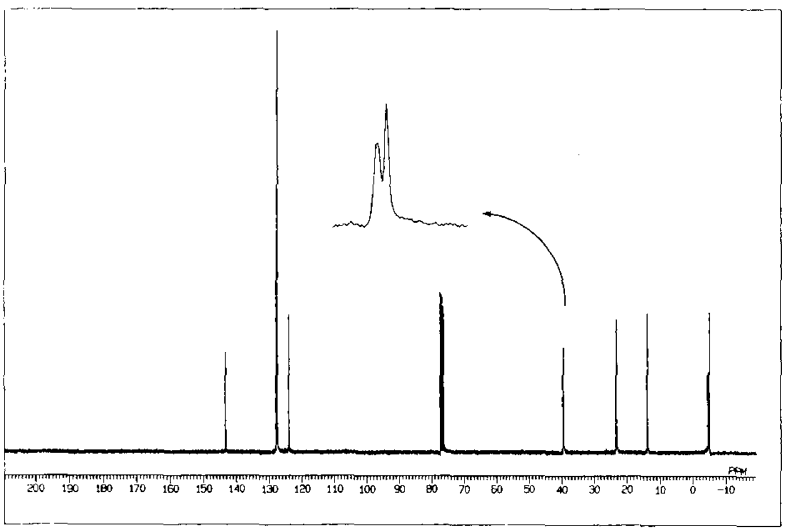

Figure 10. ${ }^{13} \mathrm{C}$ NMR spectrum of poly(1,1-dimethyl-2-phenylsilacyclobutane).

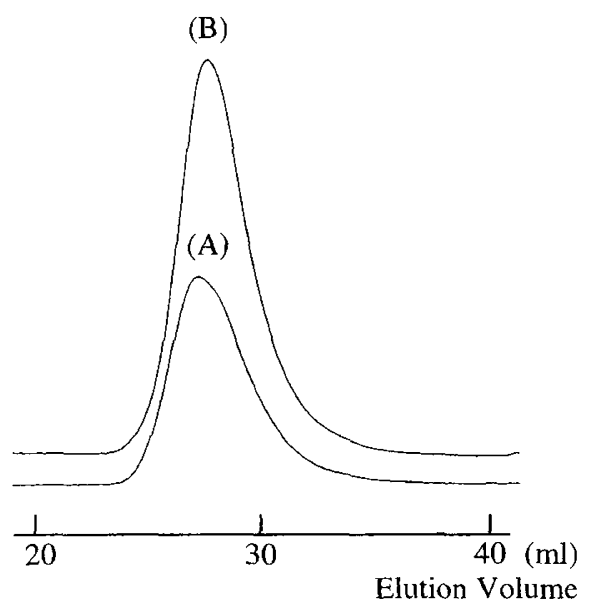

Figure 11. GPC charts: (A) poly(1,1-dimethyl-2-phenylsilacyclobutane) obtained after completion of the first polymerization step; (B) poly(1,1-dimethyl-2-phenylsilacyclobutane) obtained after completion of the second polymerization step.

been killed before the second addition of monomer.

Polymerization of 1-Methyl-1-phenylsilacyclobutane

Although we have already reported anionic polymerization of 1-methyl-1-phenylsilacyclobutane $(3),{ }^{3 \mathrm{~b}}$ we reexamined it under the same conditions to make a direct comparison with other phenyl monomers (Scheme 4). Twenty-fold moles of monomer 3 were almost consumed by butyllithium in $10 \mathrm{~min}$, which was much faster than that of monomer 1 and much slower than that of monomer 2. $M_{n}$ of the polymer obtained after quenching at $1 \mathrm{~h}$ was 8900 , this being larger than $M_{n}$ estimated from $[\mathrm{M}]_{0} /[\mathrm{I}]_{0}$ (the calculated $M_{n}=3300$ ). $M_{w} / M_{n}$ of the polymer was slightly broad (1.22). The results of the two-step monomer addition experiment were shown in Figure 12. The GPC chart became bimodal after the second polymerization step, indicating some prepolymer molecules to remain intact and others restart the polymerization to increase molecular weight. It is obvious that some polymer end groups were killed under these polymerization conditions. 


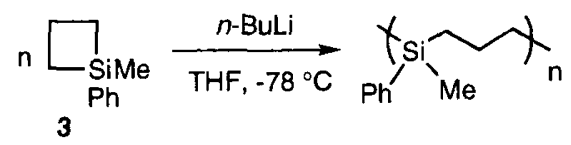

Scheme 4.

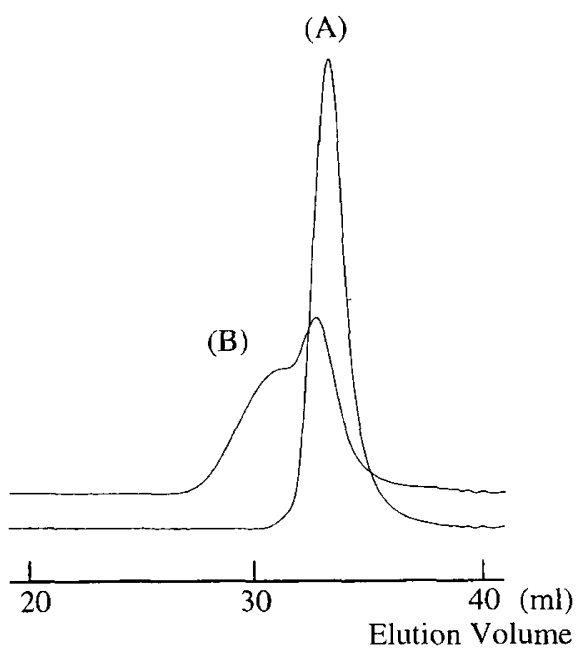

Figure 12. GPC charts : (A) poly(1-methyl-1-phenylsilacyclobutane) obtained after completion of the first polymerization step; (B) poly(1-methyl-1-phenylsilacyclobutane) obtained after completion of the second polymerization step.

\section{Differential Scanning Calorimetry (DSC) Measurement of Phenyl Substituted Polysilacyclobutane}

DSC of the phenyl-substituted polymers synthesized above was taken. Glass transitions of the polymers were observed. Glass transition temperatures $\left(T_{\mathrm{g}}\right) \mathrm{s}$ were determined at $-5^{\circ} \mathrm{C}$ for poly(1,1-dimethyl-3-phenylsilacyclobutane), $27^{\circ} \mathrm{C}$ for poly(1,1-dimethyl-2-phenylsilacyclobutane), and $-29^{\circ} \mathrm{C}$ for poly (1-methyl-1-phenylsilacyclobutane), respectively. These $T_{\mathrm{gs}}$ are much higher than those of the usual poly(1,1-dialkylsilacyclobutane)s. For instance, poly(1,1-dimethylsilaccylobutane) does not show $T_{\mathrm{g}} \mathrm{d}$ down to $-100^{\circ} \mathrm{C}$. The stiffness of the backbone increased by introducing aromatic substituents in the polymers. In spite of similar main chain structures, these three polymers synthesized here showed quite different $T_{\mathrm{g}} \mathrm{s}$. Presumably steric hindrance around phenyl groups increased in the order of poly(1-methyl-1phenylsilacyclobutane $<$ poly(1,1-dimethyl-3-phenylsilacyclobutane $)<$ poly(1,1-dimethyl-2-phenylsilacyclobutane) to prevent local thermal movement of the main chain.

\section{CONCLUSION}

We synthesized three phenyl-substituted silacyclobutanes, 1,1-dimethyl-3-phenylsilacyclobutane, 1,1dimethyl-2-phenylsilacyclobutane, and 1-methyl-1phenylsilacylcobutane, and examined anionic polymerizations. Polymerization of 1,1-dimethyl-3-phenylsilacyclobutane proceeded in a living manner, whereas that of 1,1-dimethyl-2-phenylsilacyclobutane and 1-methyl-1phenylsilacuclobutane did not. DSC measurement revealed that poly(phenylsilacylcobutane)s had a relatively high $T_{\mathrm{g}}$ compared to usual polysilacyclobutane,

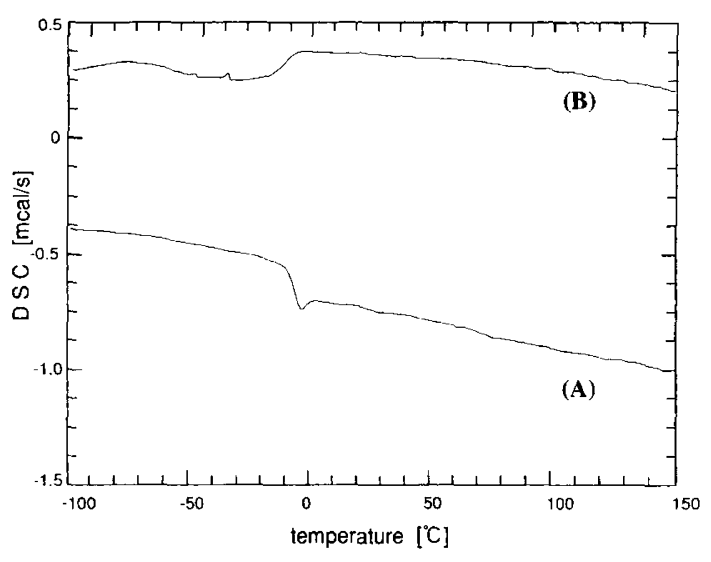

(i)

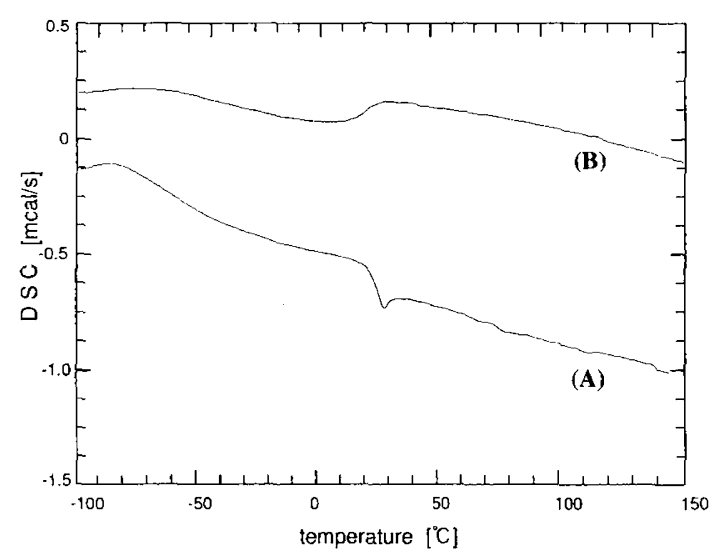

(ii)

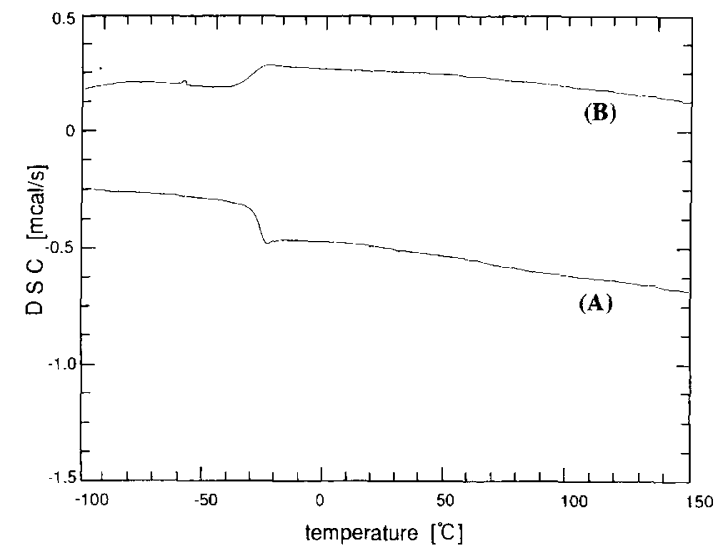

(iii)

Figure 13. DSC traces of (i) poly(1,1-dimethyl-3-phenylsilacyclobutane); (ii) poly(1,1-dimethyl-2-phenylsilacyclobutane); (iii) poly(1-methyl-1-phenylsilacyclobutane). (A) represents a heating scan at $10^{\circ} \mathrm{C} \min ^{-1}$. (B) represents a cooling scan at $10^{\circ} \mathrm{C} \mathrm{min}^{-1}$

which increased in the order of poly(1-methyl-1phenylsilacyclobutane $<$ poly(1,1-dimethyl-3-phenylsilacyclobutane $)<$ poly(1,1-dimethyl-2-phenylsilacyclobutane). These three polymers may be regarded as copolymers of silylenemethylenes and alkenes. For instance, poly(1,1-dimethyl-3-phenylsilacyclobutane) can be considered head-to-tail specific alternative copolymers of styrene and dimethylsilylenemethylene. Poly(1methyl-1-phenylsilacyclobutane) corresponds to an al- 
ternative copolymer of ethylene and methylphenylsilylenemethylene. These may constitute a new series of composite materials consisting of organosilanes and hydrocarbons. Further investigation on physical properties and applications of the living polymerization of 3 phenysilacyclobutane to a block copolymer synthesis are currently in progress.

Acknowledgments. We thank professor Koichiro Oshima and Dr. Hiroshi Shinokubo of Kyoto University for useful information on the synthesis of 3phenylsilacyclobutane. We are grateful to Dr. Minoru Nakano of Kyoto University for his suggestions about the polymerization of 3-phenylsilacyclobutane. Thanks are due to professor Mitsuo Sawamoto of Kyoto University for assistance in the ${ }^{29} \mathrm{Si}$ NMR measurements. The present work was supported by a Grant-in-aid for Encouragement of Young Scientists (No. 11750764) and by CASIO SCIENCE PROMOTION FOUNDATION.

\section{REFERENCES}

1. (a) M. Zeldin, K. J. Wynne, and H. R. Allcock, "Inorganic and Organometallic Polymers," ACS Symposium Series 360, American Chemical Society, Washington, D.C., 1988. (b) J. M. Zeigher and F. W. G. Fearon, "Silicon-Based Polymer Sci- ence," Advances in Chemistry Series 224, American Chemical Society, Washington, D.C., 1990. (c) J. G. Richard, "SiliconContaining Polymers," The Royal Society of Chemistry, Cambridge, 1995. (d) H. R. Kricheldorf, "Silicon in Polymer Synthesis," Springer-Verlag, Berlin, 1996.

2. For recent reports on polymerization of silacyclobutanes see (a) C. X. Liao and W. P. Weber, Macromolecules, 25, 1639 (1992). (b) M. Theurig, S. J. Sargeant, G. Manuel, and W. P. Weber, Macromolecules, 25, 3834 (1992). (c) M. Theurig and W. P. Weber, Polym. Bull., 28, 17 (1992). (d) C. X. Liao and W. P. Weber, Polym. Bull., 28, 281 (1992). (e) H. Yamashita, M. Tanaka, and K. Honda, J. Am. Chem. Soc., 117, 8873 (1995). (f) K. Matsumoto, K. Miyagawa, and H. Yamaoka, Macromolecules, 30, 2524 (1997). (g) K. Komuro and Y. Kawakami, Polym. J., 31, 138 (1999).

3. (a) K. Matsumoto and H. Yamaoka, Macromolecules, 28, 7029 (1995). (b) K. Matsumoto, H. Shimazu, M. Deguchi, and H. Yamaoka, J. Polym. Sci., Part A: Polym. Chem., 35, 3207 (1997). (c) K. Matsumoto, M. Deguchi, M. Nakano, and H. Yamaoka, J. Polym. Sci., Part A: Polym. Chem., 36, 2699 (1998).

4. R. Knischka, H. Frey, U. Rapp, and F. J. Mayer-Posner, Macromol. Rapid. Commun., 19, 455 (1998).

5. M. A. Umbreit and K. B. Sharpless, J. Am. Chem. Soc., 99, 5526 (1977).

6. J. G. Calzada and J. Hooz, Org. Synth., VI, 634 (1988).

7. P. B. Valkovich, T. I. Ito, and W. P. Weber, J. Org. Chem., 39, 3543 (1974).

8. H. Gilman and W. H. Atwell, J. Am. Chem. Soc., 86, 2687 (1964). 